\title{
EXAMINATION OF THIRLWALL'S LAW FOR BRIC-T COUNTRIES
}

\author{
Filiz ERATAŞ SÖNMEZ ${ }^{1}$ and Yağmur SAĞLAM²
}

\begin{abstract}
According to the Thirlwall's Law, the main factor which restricts the economic growth in an open economy is the balance of payments. The aim of this study is to investigate the validity of the Thirlwall Law for BRIC-T (Brazil, Russi India, China, Turkey) countries for the period between 2000 and 2015. Panel data analysis has been used in the empirical part of the study. Heterogeneity (vice versa) and cross-sectional dependency of the variables are examined with some preliminary tests. Respectively, Delta test and CDIm test have been applied. After proving the stability of the variables with second generation panel unit root tests, the long-term cointegration relationship is estimated by Westerlund Durbin-H test. According to the results, Thirlwall's Law is not valid for BRIC-T economies.
\end{abstract}

Keywords: Thirlwall's Law, Panel Unitroot Test, Panel Cointegration Test.

JEL Classification: C23, F41, F43.

\section{THIRWALL KANUNU'NUN BRIC-T ÜLKELERI iÇiN INCELENMESi}

Öz

Thirwall Kanunu'na göre dışa açık bir ekonomide büyüme oranını kısıtlayan ana faktör ödemeler dengesi bilançosudur. Bu çalışmadaki amaç, Thirwall Kanunu'nun 2000-2015 yıllarını kapsayan bir dönemde geçerliliğin BRIC-T (Brezilya, Rusya, Hindistan, Çin, Türkiye) ülkeleri için sınanmasıdır. Çalışmanın ampirik kısmında panel veri analizi yapılmıştır. Değişkenlerin yatay-kesit bağımlılığı içerip içermediği ya da heterojen olup olmadıkları; Delta ve CDIm gibi ön testler ile test edilmiştir. Serilerin durağanlığı ikinci kuşak birim kök testleri ile ispat edildikten sonra uzun dönem nedensellik ilişkisi Westerund Durbin-H testi ile tahmin edilmiştir. Elde edilen sonuçlara göre, Thirwall Kanunu BRIC-T ekonomilerinde geçerli değildir.

Anahtar Kelimeler: Thirwall Kanunu, Panel Birim Kök Testi, Panel Eşbütünleşme Testi.

JEL Sinıflandırması: C23, F41, F43.

${ }^{1}$ Assist. Prof., Manisa Celal Bayar University, Faculty of Economics and Administrative Sciences, Department of Economics, filiz.eratas@cbu.edu.tr. ORCID: 0000-0003-2052-340X.

${ }^{2}$ Assist. Prof., Sinop University, Faculty of Economics and Administrative Sciences, Department of Economics, yagmur.saglam@sinop.edu.tr. ORCID: 0000-0001-2345-6789. 


\section{Introduction}

The emergence of large imbalances in the current accounts of many developing economies in recent years has received much attention in the literature, renewing the debate regarding balance of payments adjustments and the concept of current-account sustainability. To the extent that they reflect the efficient inter-temporal allocation of capital, temporary current account deficits can be beneficial, but persistent deficits will lead to unsustainable balance of payments problems and, thus, to a default and/or a costly adjustment process via a fall in aggregate demand and growth. Thus, in the long-run, growth must be consistent with a sustainable current account and balance of payments equilibrium.

Post-Keynesian economists, including Thirlwall, point out that economic growth is demanddriven. According to this approach, an increase in aggregate demand puts pressure on the current account balance of the country. It results a current account deficit with having a restrictive effect on economic growth. Thirlwall states that the main factor which restricts the growth in an open economy is the balance of payments. The long-run growth rate is determined by an increase in export and by income elasticity of import demand. Than economic growth is only possible with an increase in export.

In his study, Thirwall (1979) made a comparison between calculated growth rate which has estimated under balance of payment restriction and real growth rate in developed countries. He emphasizes that the results are significantly similar. Economic structure is rapidly changing in the world, so the main question is to answer with this study is "How this change affected the validity of the Thirlwall's Law? and How it has affected the economic performance level of countries?".

The empirical studies on the validity of the Thirlwall's Law are divided into two main groups. These are time series analyses on a single country and panel data analyses allowing cross-country comparisons. The studies with time series estimate regressions for each country in a given country group and compared them one by one or a single country is analysed. In the empirical model part of this study, a panel data analysis method is used to evaluate different country groups together.

Unlike other studies in the literature, the contribution of this work to the literature is that it examines empirical model with non-stationary panel data analysis. Which also means that the heterogeneity and cross-section dependence of the variables are taken cognizance by second generation unit root test and second-generation co-integration test. Moreover, in empirical models where different countries are considered together, the results obtained from the panel data analysis are more effective and reliable than the results obtained from the time series analysis performed separately for the countries.

The rest of the study is divided into three sections. In the following section explains theoretical framework of Thirwall's Law. Section three describes the data and methodology and the validity of the Thirlwall's Law has been analysed with an econometric model in the empirical part. The results have been evaluated according to findings and the conclusion part gives some policy suggestions.

\section{Thirlwall's Law: Theoretical Framework}

The model based on the Keynesian economic theory which is developed by A. P. Thirlwall in 1979 , it is suggested that the increase in aggregate demand is the most important factor that makes a difference between the rates of economic growth between countries (Thirlwall, 1979: 4546). The argument comes from whether Thirwall model is based on supply or demand side (Kula, 2008: 61). According to the model, rising domestic demand creates pressure on balance of payments via increasing import rate exchange of the country due to increasing import. Therefore, balance of payments plays a limiting role on economic growth.

According to Post-Keynesians, including Thirlwall, in the long-term balance of payments can be funded by only rising export. Because funding current account deficit with short-term capital flows is unstable and it has risky structure due to the short-term ambitions of foreign investors (Leon- 
Ledesma, 1999: 431). According to Thirlwall's Law, the growth rate of an open economy is determined by export performance of that country.

Thirlwall's Law is also taking its source from the long-term dynamic Harrod foreign trade multiplier. The Harrod foreign trade multiplier assumes that the terms of trade, savings and investments are fixed (constant), at the same time there is no state intervention (Kula, 2008: 60, Yamak and Abdioğlu, 2010: 444-445).

According to the Thirlwall's Law, the equation of balance of payments can be written as follow:

$\mathrm{P}_{\mathrm{d}} \mathrm{X}=\mathrm{P}_{\mathrm{f}} \mathrm{M}$

In equation number (1) above;

$\mathbf{P}_{\mathbf{d}}$ : refers to domestic prices (the price of exported goods),

$\mathbf{P}_{\mathbf{f}}$ : refers to foreign prices (the price of imported goods),

$\mathbf{X}$ : shows amount of export,

M: shows amount of import,

E: refers to exchange rate.

The Thirlwall model describes export and import functions as follows (Thirlwall, 1979: 47-48):

$$
\begin{aligned}
& X=b\left(\frac{P_{d}}{P_{f} E}\right)^{\eta} Y^{* \varepsilon} \\
& M=a\left(\frac{P_{f} E}{P_{d}}\right)^{\psi} Y^{\pi}
\end{aligned}
$$

$\mathbf{a}$ and $\mathbf{b}$ : refer to a constant number,

$\eta$ : refers to price flexibility of export,

$\boldsymbol{\varepsilon}$ : refers to foreign income elasticity of export,

Y*: shows the level of income on abroad,

$\Psi$ : shows the price elasticity of import,

$\pi$ : shows the income elasticity of import,

Y: refers to the level of domestic income.

Following equations are the logarithmic forms of the equations 2 and 3, written as follow:

$$
\begin{aligned}
& \mathrm{x}=\eta\left(\mathrm{p}_{\mathrm{d}}-\mathrm{p}_{\mathrm{f}}-\mathrm{e}\right)+\varepsilon \mathrm{y}^{*} \\
& \mathrm{~m}=\psi\left(\mathrm{p}_{\mathrm{f}}+\mathrm{e}-\mathrm{p}_{\mathrm{d}}\right)+\pi
\end{aligned}
$$

Following equation is the logarithmic form of equation (1) and expressed as follows:

$$
\mathrm{p}_{\mathrm{d}}+\mathrm{x}=\mathrm{p}_{\mathrm{f}}+\mathrm{m}+\mathrm{e}
$$

When the equations 2 and 3 are substituted in equation 6 , the restricted growth rate of balance of payments is calculated, which is found by Thirlwall. The restricted growth rate of balance of payments is expressed by the equation 7 below:

$$
\mathrm{y}_{\mathrm{BP}}=\left[(1+\eta+\psi)\left(\mathrm{p}_{\mathrm{d}}-\mathrm{p}_{\mathrm{f}}-\mathrm{e}\right)+\varepsilon \mathrm{y}^{*}\right] / \pi
$$

Thirlwall (1979) adopts the equation $\left(\mathrm{p}_{\mathrm{d}}-\mathrm{p}_{\mathrm{f}}-\mathrm{e}\right)=0$. Because it assumes that real terms of trade are fixed in the long-run. According to this assumption, the restricted growth rate of the balance of payments is expressed as follows:

$$
\mathrm{y}_{\mathrm{BP}}=\frac{\varepsilon \mathrm{y}^{*}}{\pi}=\frac{\mathrm{x}}{\pi}
$$




\section{Literature Review}

The empirical studies on the validity of the Thirlwall's Law are divided into two main groups. These are time series analyses on a single country and panel data analyses allowing cross-country comparisons. The studies with time series estimate regressions for each country in a given country group and compared them one by one or a single country is analysed. For example, Thirlwall and Hussain (1982) find that the Thirlwall's Law is invalid for the period between 1953 and 1978 for eleven selected oil producers and Middle East countries.

In his work on oil exporters and other 15 developing countries, Bariam (1990) concludes that during the 1960 and 1985, the Thirlwall's Law is valid for the other developing countries that are not petroleum exporters. He uses Ordinary Least Squares (OLS) method and compared calculated growth rates and real growth rates. Bairam (1993), teste Harrod dynamic multiplier for 5 developed European countries with OLS method during 1970 and 1989. The validity of Thriwall Law has been tested and according to the results, calculated growth rates under the restriction of balance of payments are like the real growth rates.

Ateşoğlu (1993) examines United States of America (USA) for the period between 1955 and 1990. He stated that the Thirlwall's Law is valid, and this result supports the demand-driven Keynesian growth theory and does not support supply-driven Neoclassical growth theory. Ateşoğlu (1994) claims that there is a high correlation between restricted growth rates of balance of payments and the real growth rates under the hypothesis of Thirlwall's Law in Germany during 1960 and 1990. A decrease in real export is the reason of a decrease in growth rate in the longterm

McCombie (1997) tests UK, USA and Japan economies for the period between 1952 and 1993 with unit root test that takes structural breaks into account and with OLS method. Thirlwall Law is valid after the Cold War for England and USA because calculated growth rates and real growth rates are similar. But the Thirlwall's Law is invalid in Japan because of the marked difference between the growth rates.

Hussian (1999) explains that in 29 African and 11 Asian countries, restricted growth rates and real growth rates showed important similarity in African countries unlike Asian countries. Also, low growth rates in African countries were caused by low export performance in the context of the Thirlwall Law. Spanish economy is examined for the period between 1965 and 1993 in his study, Leon-Ledesma (1999) states that the real growth rates and the growth rates calculated under the restriction of the balance of payments are very similar to each other. Lopez and Cruz (2000) conclude that Thirlwall's Law is valid in 4 Latin American countries for the period between 1965 and 1996 with VAR analysis. Moreno-Brid and Merez (1999) study with 5 Latin American countries during the period 1950-1996 and argued that there is a strong relationship between long-term growth rate and real export. They have reached the conclusion that the Thirlwall's Law is valid for open Latin American economies. Turner (1999) emphasises that Thirwall's Law is valid for G7 countries. He uses cross-country comparisons and tested the period between 1956 and 1973 with OLS method. Perraton (2003) estimates the model with the OLS method in his study for 27 developing countries with middle and lower income levels during the period between 1973 and1995. He states that the Thirlwall's Law is valid, and the growth figures calculated under the restriction of balance of payments and real ones are significantly similar.

Bertola et al. (2002) use a time-series test of Thirlwall's Law for Brazil during the period of 18901973. The empirical results confirm the existence of a long-run relationship between Brazilian GDP, terms-of-trade and world income, as Thirlwall's Law predicts. In addition, an error correction model is estimated, which shows that adjusting toward Thirlwall's Law equilibrium explains a substantial part of total variation of real GDP in the short run.

Loria (2003) argues that the main constraint for the Mexican economy to grow remains inside the structural deficit of the current account as well as in the real exchange rate level. An annual 
structural econometric model is estimated to identify the determinants of the four balances that constitute the current account balance for the period of 1970-1999, which estimated through weighted two-stage least square. As in other empirical works, he proved that a clear long-run trade-off between economic growth and the external balance has always existed.

Kvedaras (2005) works on 10 Central and Eastern European countries during the period between 1995 and 2004. Error Correction Mechanism (ECM) model has been preferred. According to findings, Thirlwall's Law is valid in Bulgaria, Hungary and the others, which have higher economic growth performance than group average except Slovenia, which has lower growth performance than the group average. Razmi (2005) applies the balance-of-payments-constrained growth model to India, a large developing country with a relatively low trade to GDP ratio. The average growth rates predicted by various forms of the BPCG hypothesis are found to be close to the actual average growth rate over the period of 1950-1999.

Pacheco-Lopez and Thirlwall (2006) teste 17 Latin American countries with pooled regression estimation method. For the selected period which is between 1977 and 2002, Thirlwall's Law is valid only for Chile and Venezuela when trade liberalization is considered. Vera (2006) develops a general extended version of the balance-of-payments-constrained growth model that takes into account three often ignored aspects of contemporary growth in open economies, trade imbalances and the importance of net financial flows in the long-run, relative price changes caused by idiosyncratic rules of adjustment in prices, and trade and payments interdependence among asymmetric regions. He found that an exogenous change in the rate of growth of financial transfers may generate either a mutually reinforcing growth regime or a conflicting growth regime. The general equilibrium solution encompasses all these cases and allows us to evaluate certain conditions under which the South's real output will grow at a lower rate than the North.

Elitok and Campbel (2008) reach the conclusion that the Thirlwall's Law is valid for Turkish economy during the period of 1960-2004 according to the results obtained with OLS method. Kula (2008), Thirlwall's Law is not valid for Turkish economy during 1980-2006, because there were significant differences between estimated rates under the restriction of balance of payments and real growth rates.

Garcimartin et al. (2008) present a continuous-time disequilibrium model to explain economic growth in Ireland. They try to identify the key factors explaining the Irish miracle by developing a demand-oriented growth accounting methodology based on the balance-of-payments-constraint theory in the period of 1960-2000. It is founded that evidence to support the hypothesis that the Irish economy has been balance-of-payments constrained rather than resource constrained.

Britto and McCombie (2009) use the balance-of-payments-constrained model to estimate the determinants of the long-run rate of growth of Brazil. They used a different approach to test the long-run relationship between actual growth rates and those predicted by Thirlwall's Law, extended to include capital flows the period of 1951-2005 by VAR model. The regression results, apart from providing renewed support for the thesis that the country's growth rate has been constrained by the balance of payments, allow us to argue that Thirlwall's Law is associated with a notion of long-run equilibrium growth rate which is fundamentally distinct from that of mainstream economics.

Bagnai (2010) reaches the conclusion that the Thirlwall's Law is valid for 22 OECD countries during 1960-2006, results are based on the unit root tests that take structural breaks into account and the empirical model tested by co-integration test. Gouvea and Lima (2010) examined the validity of the Thirlwall's Law with multi-sectoral analysis considering structural changes, and with OLS method for Latin American and Asian countries during the period 1962-2006. Because of the multi-sectoral analysis, Thirlwall's Law is valid for all countries except in South Korea. According to OLS test results, Thirlwall's Law is valid for all selected countries. 
Soukiazis and Antunes (2011) present a model to verify whether the balance-of-paymentsconstrained growth approach is suitable for explaining the Portuguese growth performance during the period of 1965-2008. It is shown that actual growth can accurately be predicted by the ratio of export growth to the income elasticity of the demand for imports. Considering the pre and postaccession periods to the European Union, it is found that Portugal grew at a slower rate in the latter period, explained by a higher income elasticity of imports and lower export growth.

Tuncer et al. (2011) have examined the validity of Thirlwall's Law for specified period between 1982 and 2010. Empirical findings obtained by using ARDL method show that Thirlwall's Law is valid in Turkish economy. Yamak and Abdioğlu (2010) investigate the validity of Thirlwall's Law in Turkish economy for the period between 1982 and 2008. They state that according to the OLS analysis and Kalman filter, it is accepted that Thirwall's Law is valid in Turkey. Halıcıoğlu (2012) reached the conclusion that Thirlwall's Rule is not valid in Turkey according to the results obtained from ARDL method for the period of 1980-2008. Arıcıoglu et al. (2013) investigated the validity of the Thirlwall's Law in Turkish economy for the period between 1987: Q1 and 2011: Q4 with ARDL method. According to empirical results Thirlwall's Law is not valid for the selected period.

Tharnpanich and McCombie (2013) test the balance-of-payments constrained growth model for Thailand. They found that Thailand's long-run economic growth over the period 1962-2009 is balance-of-payments constrained. Besides the positive effect of export growth, changes in the terms of trade also played a role but had an adverse effect on the growth performance of Thailand. Tekgül and Cin (2013),

Alencar and Strachman (2014) use vector error correction model to test the validity of Thirlwall's Law. They claim that the rate of economic growth in Brazil was restricted by the external sector in the period of 1951-2008, validating the theory of balance-of-payments growth constraint with regard to the economic history of Brazil.

Bagnai et al. (2015) examine the long run relationship between economic growth and current account equilibrium in Vietnam, using a multi-country balance-of-payments-constrained growth model. They find that Vietnam grew less than the rate predicted by the model in the period of 1985-2010. They also find that the balance-of-payments-constrained growth rate shifted after the 1997 Asian crisis. Since the relative price effect is neutral, the volume effects dominate in setting the balance-of-payments constraint.

Dilber and Erataş Sönmez (2016) tested the validity of the Thirlwall's Law for develop countries (G7 countries) for the period of 1980-2014 with non-stationary panel data analysis. They expressed that Thirlwall's Law is not valid for selected countries.

Podkaminer (2017), he uses Autoregressive Distributed Lags (ARDL) approach to establish the empirical adequacy of the Law. The analysis, working with data for 58 countries and covering the years 1960-2012, suggests that the Law may not hold for most countries considered. Romero and McCombie (2017), they use system GMM model and state that the growth rates of exports and imports are partially determined by the growth rate of relative economic efficiency or total factor productivity, which suggests that more information on the determinants of trade can be obtained by using expanded export and import functions.

The empirical model of this study is based on the work of Lanzafame (2013). This is because none of these methods used in previous studies involve dynamic panel data analysis. The validity of the Thirlwall's Law is tested by panel ARDL (Auto Regressive Distributed Lag) method and panel causality was examined by Granger Panel Causality Test. It is concluded that the Thirlwall's Law is valid or not in BRIC-T countries.

\section{Data}

The aim of this study is to test the validity of the Thirlwall's Law for developing countries for the period between 2000 and 2015. The empirical model is based on BRIC-T countries' (Brazil, 
Russia, India, China and Turkey) annual data of import volume, relative prices and real GDP growth rate.

The empirical panel data analysis is stated as follows:

$\log \operatorname{Im} \operatorname{Vol}_{i, t}=b_{0}+b_{1} \log R P_{i, t}+b_{2} \log G P_{i, t}+\varepsilon_{i, t}$

Im Vol.: Import Volume

RP: Relative Prices

GDP: Real GDP (Constant prices, USD)

The data set is obtained from World Bank and IMF World Economic Outlook database.

\section{Methodology and Empirical Findings}

\subsection{Heterogeneity}

As a starting point, homogeneity of the variables has been examined by delta test. Homogeneity of the series influences structures of following panel unit root and panel cointegration tests. Delta test is slope homogeneity test which used to in the panel data models when the cross-section dimension $(N)$ is larger than the relative time dimension $(T)$. This test use of the cross-section distribution of individual slopes weighted by their relative accuracy. With strictly exogenous regressor models with non-normally distributed errors, the test has a standard normal distribution. When the errors are normally distributed, a mean-variance of the bias adjusted version of the test is distributed normally irrespective of the relative expansion rates of $\mathrm{N}$ and $\mathrm{T}$. The test is also applied to static models and shown to be prevailing asymptotically providing that $\mathrm{N} / \mathrm{T} \rightarrow \mathrm{K}$, as $(\mathrm{N}, \mathrm{T}) \rightarrow^{\mathrm{j}} \infty$, where $0 \leq \mathrm{K}<\infty$. It is proven that the test has the correct size and satisfactory power in panel data models with sternly exogenous regressors for varied combinations of $\mathrm{N}$ and $\mathrm{T}$ by using Monte Carlo experiments. Equivalent results are also obtained for dynamic panel data models if the autoregressive coefficient is not so close to unity and providing that $\mathrm{T} \geq \mathrm{N}$ (Pesaran and Yamagata, 2008:50).

The delta tests are calculated as below

$$
\begin{aligned}
& \tilde{\Delta}=\sqrt{\mathrm{N}} \frac{\mathrm{N}^{-1} \check{\mathrm{S}}-\mathrm{k}}{\sqrt{2 \mathrm{k}}} \\
& \tilde{\Delta}_{\mathrm{adj}}=\sqrt{\mathrm{N}} \frac{\mathrm{N}^{-1} \breve{\mathrm{S}}-\mathrm{k}}{\sqrt{\operatorname{Var}(\mathrm{T}, \mathrm{k})}}
\end{aligned}
$$

Equation 10 represents delta test statistics for small samples while equation 11 shows adjusted delta test statistics for large ones (Pesaran and Yamagata, 2008:57).

Null and alternative hypotheses can also be stated as (Pesaran and Yamagata, 2008:56):

$$
\begin{aligned}
& \mathrm{H}_{0}: \beta_{1}=\beta_{2}=\cdots=\beta_{\mathrm{n}}=\beta \text { (for all } \beta_{\mathrm{i}} \text { ), } \\
& \mathrm{H}_{1}: \beta_{1}=\beta_{2}=\cdots \neq \beta_{\mathrm{n}} \text { (at least for one } \mathrm{i} \text { ). }
\end{aligned}
$$

Table 1: Delta Test Result

\begin{tabular}{ccl}
\hline Test & T-Statistics & Prob. \\
\hline$\tilde{\Delta}$ & 1.770 & $0.038^{*}$ \\
$\tilde{\Delta}_{\text {adj }}$ & 2.024 & $0.021^{*}$ \\
\hline
\end{tabular}

$(*)$ represents significance level in $5 \%$.

Considering to the Table 1, the variables in empirical model are heterogeneous. Because given probability value is smaller than 0.05 and it's clear that prob values are significant and $\mathrm{H}_{0}$ null hypothesis is rejected. Both the delta test $\tilde{\Delta}$ used for large sample and the delta test $\tilde{\Delta}_{\text {adj }}$ used for small sample are significant at 5\% level. 
This means that the slope coefficients of the panels are heterogeneous, varying with respect to the $h$ cross-section units, and the heterogeneity of the variables must be considered throughout the stationary and cointegration tests to be performed at a later stage.

\subsection{Cross-section Dependency}

It's essential to find out the cross-sectional independencies for the series which are proven to be heterogeneous with the delta test. The independence of the cross-sectional data can also be stated as to whether all the cross-sectional data be affected equally by a shock at any time or not.

The $\mathrm{CD}_{\mathrm{LM}}$ test statistic is to be obtained by the equation above in order to examine the crosssectional independence. A contemporaneous correlation, low or high, is expected between the residuals.

There are several tests to examine the cross-section dependency in panel data models. In this study LM test, CD LM1 test, CD LM2 test and Bias-Adjusted CD test have been used.

This test based on the following LM test (Pesaran, 2004:4):

$$
\mathrm{LM}=\mathrm{T} \sum_{\mathrm{i}=1}^{\mathrm{N}-1} \sum_{\mathrm{J}=\mathrm{i}+1}^{\mathrm{N}} \hat{\rho}_{\mathrm{ij}}^{2}
$$

The CD LM1 is a test to analyse cross-section dependency is calculated as below (Pesaran, 2004:5):

$$
\mathrm{CD} \mathrm{LM}_{1}=\sqrt{\frac{1}{\mathrm{~N}(\mathrm{~N}-1)}}\left[\sum_{\mathrm{i}=1}^{\mathrm{N}-1} \sum_{\mathrm{j}=\mathrm{i}+1}^{\mathrm{N}}\left(\mathrm{T} \hat{\mathrm{\rho}}_{\mathrm{ij}}{ }^{2}-1\right)\right] \sim \mathrm{N}(0,1)
$$

In equation $5, \hat{\rho}_{\mathrm{ij}}$ shows the prediction aggregate of cross-sectional residuals. This test used to when $\mathrm{N}$ and $\mathrm{T}$ are large $(\mathrm{T} \rightarrow \infty$ and $\mathrm{N} \rightarrow \infty)$, is asymptotically normal distribution. CD LM 1 test is hinge on the sum of correlation coefficient squares between the cross-sectional residuals. CD LM 1 test is used to when the time dimension larger than the cross-section dimension and/or the crosssection dimension larger than the time dimension, as well. The null and alternative hypothesis of these tests is alike for all.

The CD LM 2 test is diverse test to analyse cross-section dependency is calculated with the equation above (Pesaran, 2004:5):

$$
\mathrm{CD} \mathrm{LM}_{2}=\sqrt{\frac{2 \mathrm{~T}}{\mathrm{~N}(\mathrm{~N}-1)}}\left[\sum_{\mathrm{i}=1}^{\mathrm{N}-1} \sum_{\mathrm{j}=\mathrm{i}+1}^{\mathrm{N}} \hat{\rho}_{\mathrm{ij}}\right] \sim \mathrm{N}(0,1)
$$

Bias-Adjusted CD LM test which was developed by Pesaran et al (2007), is a modified version of the CD LM2 test. Beneath the alternative hypothesis of a $p^{\text {th }}$ order local dependence, Pesaran (2004) suggests a $p^{\text {th }}$ order generalization of the CD test as specified below (Pesaran et al., 2007:110)

$$
\begin{aligned}
& \operatorname{CD~LM}_{\mathrm{ADJ}}=\sqrt{\frac{2 \mathrm{~T}}{\mathrm{p}(2 \mathrm{~N}-\mathrm{p}-1)}}\left(\sum_{\mathrm{s}=1}^{\mathrm{p}} \sum_{\mathrm{i}=1}^{\mathrm{N}-\mathrm{s}} \hat{\rho}_{\mathrm{i}, \mathrm{i}+\mathrm{s}}\right. \\
& \mathrm{H}_{0}: \operatorname{Cov}\left(\mathrm{u}_{\mathrm{it}}, \mathrm{u}_{\mathrm{jt}}\right)=0 \text { for all } \mathrm{t} \text { and } \mathrm{i} \neq \mathrm{j}, \\
& \mathrm{H}_{1}: \operatorname{Cov}\left(\mathrm{u}_{\mathrm{it}}, \mathrm{u}_{\mathrm{jt}}\right) \neq 0 \text { for some } \mathrm{t} \text { and } \mathrm{i} \neq \mathrm{j} .
\end{aligned}
$$


Table 2: Cross-section Dependency Tests Results

\section{Cross-section Dependency Test (Model)}

\begin{tabular}{lcl}
\hline \multicolumn{1}{c}{ CD Test } & T-Statistics & Prob \\
\hline LM (Breusch, Pagan 1980) & 59.858 & $0.000^{*}$ \\
CD LM 1 (Pesaran 2004) & 11.149 & $0.000^{*}$ \\
CD LM 2 (Pesaran2004) & 6.984 & $0.000^{*}$ \\
Bias-adjusted CD (Pesaran et all. 2007) & 8.782 & $0.000^{*}$ \\
\hline
\end{tabular}

Cross-section Dependency Test (Im. Vol.)

\begin{tabular}{lcl}
\hline \multicolumn{1}{c}{ CD Test } & T-Statistics & Prob \\
\hline LM (Breusch, Pagan 1980) & 17.056 & $0.073^{* *}$ \\
CD LM 1 (Pesaran 2004) & 1.578 & $0.057^{* *}$ \\
CD LM 2 (Pesaran2004) & -2.531 & $0.006^{*}$ \\
Bias-adjusted CD (Pesaran et all. 2007) & 1.477 & $0.007^{*}$ \\
\hline
\end{tabular}

Cross-section Dependency Test (RP)

\begin{tabular}{lll}
\hline CD Test & T-Statistics & Prob \\
\hline LM (Breusch, Pagan 1980) & 15.345 & $0.020^{*}$ \\
CD LM 1 (Pesaran 2004) & 1.195 & 0.116 \\
CD LM 2 (Pesaran2004) & -2.424 & $0.008^{*}$ \\
Bias-adjusted CD (Pesaran et all. 2007) & 1.718 & $0.043^{*}$ \\
\hline
\end{tabular}

Cross-section Dependency Test (GDP)

\begin{tabular}{lcc}
\hline \multicolumn{1}{c}{ CD Test } & T-Statistics & Prob \\
\hline LM (Breusch, Pagan 1980) & 36.354 & $0.000^{*}$ \\
CD LM 1 (Pesaran 2004) & 5.893 & $0.000^{*}$ \\
CD LM 2 (Pesaran2004) & -2.720 & $0.003^{*}$ \\
Bias-adjusted CD (Pesaran et all. 2007) & 2.645 & $0.004^{*}$ \\
\hline
\end{tabular}

$\left({ }^{*}\right)$ and $\left({ }^{* *}\right)$ represent respectively significance level in 5 and $10 \%$.

Considering to Table 2, the null hypothesis which claims that cross-section independence of variable in the model. There is a dependence among all the cross-section units. The null hypothesis is rejected, because the probability values are smaller than 0.05 and 0.10 . So, it's possible to say that there is a dependence among the cross-sections composing Im Vol, RP and GDP.

If horizontal section dependency is not taken into consideration, traditional panel predictors can produce misleading or inconsistent parameters. For this reason, cross-section dependence is considered to be both variable and model testing at some point is important. This means, in the panel created for BRIC-T countries, either from time to time or from spatial shocks the crisis that may arise in any country is also affecting other countries.

\subsection{Stationary}

Unit root tests which consider the cross-section dependency are called "second generation panel unit root tests". Pesaran (2007) evolved a panel unit root test which consider the crosssectional dependence, instead of the factor structures of the residuals. This method is called CrossSectionally Augmented Dickey-Fuller (CADF) test and depend on the estimation of the regression below (Pesaran, 2007:268): 


$$
\begin{aligned}
& \Delta \mathrm{Y}_{i t}=\alpha_{\mathrm{i}}+\mathrm{b}_{\mathrm{i}} \mathrm{y}_{\mathrm{i}, \mathrm{t}-1}+\sum_{\mathrm{j}=1}^{\mathrm{p}_{\mathrm{i}}} \mathrm{c}_{\mathrm{ij}} \Delta \mathrm{Y}_{\mathrm{i}, \mathrm{t}-\mathrm{j}}+\mathrm{d}_{\mathrm{i}} \mathrm{t}+\mathrm{h}_{\mathrm{i}} \overline{\mathrm{y}}_{\mathrm{t}-1}+\sum_{\mathrm{j}=0}^{\mathrm{p}_{\mathrm{i}}} \eta_{\mathrm{u}} \Delta \overline{\mathrm{y}}_{\mathrm{i}, \mathrm{t}-\mathrm{j}}+\varepsilon_{\mathrm{i}, \mathrm{t}} \\
& \mathrm{H}_{0}: \mathrm{b}_{\mathrm{i}}=0 \text { stationary, } \\
& \left.\mathrm{H}_{1}: \mathrm{b}_{\mathrm{i}}<0 \text { non-stationary (for } \mathrm{i}=1,2, \ldots, \mathrm{N}\right) .
\end{aligned}
$$

T-values which belong to $b_{i}$ have been calculated by CADF test and critical values have been tabulated by Pesaran (2007). Also, Monte Carlo simulations proved that CADF test is valid in both $\mathrm{N}>\mathrm{T}$ and $\mathrm{T}>\mathrm{N}$ conditions.

T-statistic of CADF test can be calculated as follows (Pesaran, 2007:269):

$$
\mathrm{t}_{\mathrm{i}}(\mathrm{N}, \mathrm{T})=\frac{\Delta \mathrm{Y}_{\mathrm{i}} \overline{\mathrm{M}_{\mathrm{W}}} \mathrm{Y}_{\mathrm{i}-1}}{\widehat{\sigma}\left(\mathrm{Y}_{1-1}^{\prime} \overline{\mathrm{M}_{\mathrm{W}}} \mathrm{Y}_{\mathrm{i}-1}\right)^{1 / 2}}
$$

Also, another statistic called CIPS is the mean of the t-statistics for each cross-section (Pesaran 2007).

$$
\overline{\mathrm{t}}=\mathrm{N}^{-1} \sum_{\mathrm{i}=1}^{\mathrm{N}} \mathrm{t}_{\mathrm{i}}(\mathrm{N}, \mathrm{T})
$$

Table 3: CADF Test Results for Selected Variables

\begin{tabular}{ccc}
\hline CADF t-statistic values for Im. Vol. & CADF t-statistic values for RP & CADF t-statistic values for GDP \\
\hline-2.288 & -1.266 & 0.933 \\
-3.354 & -5.374 & -3.445 \\
-1.628 & -1.354 & -5.443 \\
-1.264 & -2.101 & -1.785 \\
-2.266 & -2.504 & -1.690 \\
CIPS $=-4.088$ & CIPS $=-2.520$ & CIPS $=-2.266$ \\
\hline
\end{tabular}

According to the findings which have presented in table 3, variable of Im Vol is not stationary. Calculated CADF statistics are bigger than the critical value of -4.17 (with intercept and trend) from Pesaran critical value table (Pesaran, 2007: 276), so $\mathrm{H}_{0}$ is rejected. The import volume has unit root and it is non-stationary on the level. Variable of RP is not stationary. Calculated CADF statistics are bigger than the critical value of -4.17 (with intercept and trend) from Pesaran critical value table (Pesaran, 2007: 276), so $\mathrm{H}_{0}$ is rejected. Relative Prices has unit roots and variables are nonstationary on the level. Variable of GDP is non-stationary. Calculated CADF statistics are bigger than the critical value of -4.17 (with intercept and trend) from Pesaran critical value table (Pesaran, 2007: 276), so $\mathrm{H}_{0}$ is rejected. The Gross Domestic Product has unit root and variables are nonstationary on the level.

To sum up, all the variables that make up the panel have a unit root and it means that they are non-stationary on the level. All the variables exhibit the I (1) characteristic. Therefore, there should be a second-generation panel cointegration test considering the I (1) characteristic of the variables to be applied in the next stage. In this context, Durbin $\mathrm{H}$ panel cointegration test is used to examine the cointegration relationship between the variables.

\subsection{Panel Cointegration}

The results, which are obtained from panel unit root tests, are crucial for the panel cointegration tests. While setting up the assumptions for the panel cointegration tests, considering stationarity orders of the variables can change the type of the test. Series taken into consideration exhibit cross-sectional dependency, which suggests using second generation panel cointegration tests that takes it into consideration.

Westerlund (2008) developed two panel cointegration tests depending on the Durbin $\mathrm{H}$ test. One of them DHg are called group mean statistics (for heterogeneous variables), and the other one 
is $\mathrm{DHp}$ called panel statistics (for homogenous variables). The Westerlund Durbin $\mathrm{H}$ test assumes that the series in the panel are at the same level and first differences I (1) are stationary (Westurlund, 2008:203).

Panel cointegration statistics are calculated as follows:

$$
\begin{aligned}
& \mathrm{DH}_{\mathrm{g}}=\sum_{\mathrm{i}=1}^{\mathrm{n}} \widehat{\mathrm{S}}_{\mathrm{i}}\left(\widetilde{\phi}_{\mathrm{i}}-\widehat{\phi}_{\mathrm{i}}\right)^{2} \sum_{\mathrm{t}=2}^{\mathrm{T}} \hat{\mathrm{e}}_{\mathrm{it}-1}^{2} \\
& \mathrm{DH}_{\mathrm{p}}=\widehat{\mathrm{S}}_{\mathrm{n}}(\widetilde{\phi}-\widehat{\phi})^{2} \sum_{\mathrm{i}=1}^{\mathrm{n}} \sum_{\mathrm{t}=1}^{\mathrm{T}} \hat{\mathrm{e}}_{\mathrm{it}-1}^{2}
\end{aligned}
$$

Null and alternative hypotheses of Durbin $\mathrm{H}$ test are written as follows:

$\mathrm{H}_{0}: \phi_{\mathrm{i}}=1$ there is no cointegration for all cross-section units

$\mathrm{H}_{1 \mathrm{a}}: \phi_{\mathrm{i}}=\phi<1$ there is a cointegration for all cross-section units.

$\mathrm{H}_{1 \mathrm{~b}}: \phi_{\mathrm{i}}<1$ there is a cointegration for all cross-section units.

Table 4: Durbin H Test Results

\begin{tabular}{lcc}
\hline & Test Statistics & Bootstrap Prob. \\
\hline $\mathbf{D H}_{\mathbf{p}}$ & -0.728 & 0.767 \\
$\mathbf{D H}_{\mathbf{g}}$ & -0.975 & 0.835 \\
\hline
\end{tabular}

According to the results, null hypothesis is accepted. Bootstrap probability values are taken into account because of the cross-sectional dependency when the numerical values are being interpreted. The results prove that there is no cointegration relationship among all the crosssection units. Because, given bootstrap values are not significant at $\% 5$ level, they bigger than 0.05 .

It's possible to say import volume, relative prices and GDP growth rate don't move together in the long-term. So, since there is no cointegration relationship among the variables don't move together in the long-run, we could not proceed other steps in the context of panel data analysis. It means that balance-of-payments-constrained growth rates can't calculated for the BRIC-T economies.

\section{Conclusion}

Economic growth is one of the most discussed topics in the economic literature. Supply-side approach of Neo-classical growth models are not supported in heterodox economics literature and alternative models are offered. Thirlwall's Law, which is developed based on Keynesian theory, is an important alternative approach in the literature of heterodox economics.

Thirlwall's Law, demand-side theory, is an export-driven economic growth model. Thirlwall defends that, like many Post Keynesian economists, difference in growth rates between countries originated by the growth differences in the total demand of countries. According to Thirlwall, in open economies, the main factor affecting growth is the balance of payments. This constraint on economic growth is determined by export performance income elasticity of import demand.

In empirical model, panel data analysis is used. First, slope heterogeneity of variables is examined by Delta test. Variables determined to be heterogeneous are investigated by CD LM test and the results emphasized that there is a cross-section dependency among all the units within panel. Since there is a cross-section dependence, stationary of variables is analysed with second generation panel unit root tests. According to the Pesaran (2007) CADF test results, there is a unit root and it is understood that variables of the model are non-stationary on the level. To estimate long-term vector there needs to be a cointegration relationship between the variables. The empirical findings show that there is no cointegration relationship among all the cross-section units. 
In this study, according to results, Thirlwall's Law is not valid for BRIC-T economies, because balance-of-payments-constrained growth rates can't calculate for the BRIC-T economies. It makes us think that there is a meaningful difference between the predicted rates of economic growth by the Thirlwall model and the actual rates of economic growth. When the findings are evaluated, first reason that comes to mind is the effect of the foreign capital flows on the balance of payments. If foreign capital flows are used for the financing of balances, besides the foreign trade constraint, it is possible to talk about an economic growth performance in which international capital flows play a crucial role.

\section{References}

Alencar, A. D. and Strachman, E. (2014). Balance-of-payments-constrained Growth in Brazil: 19512008. Journal of Post Keynesian Economics, 36(4), 673-698.

Arıcıoğlu, E., Ucan, O. and Saraç, T. B. (2013). Thirlwall's Law: The Case of Turkey, 1987-2011. International Journal of Economics and Finance, 5(9), 59-68.

Ateşoğlu H. S. (1993). Balance of Payments Constrained Growth: Evidence from the United States. Journal of Post Keynesian Economics, 1(4), 507-514.

Ateşoğlu, H. S. (1994). Balance of Payments Determined Growth in Germany. Applied Economic Letters, 1(6), 89-91.

Bagnai, A. (2010). Structural Changes, Cointegration and The Empirics of Thirlwall's Law. Applied Economics, 42, 1315-1329.

Bagnai, A., Rieber, A. and Tran T. A-H. (2015). Economic Growth and Balance-of-paymentconstraint in Vietnam. Journal of Post Keynesian Economics, 38(4), 588-615.

Bairam, E. (1990). The Harrod Foreign Trade Multiplier Revisited. Applied Economics, 22(6), 711718.

Bairam, E. (1993.) Static versus Dynamic Specifications of the Harrod Trade Multiplier. Applied Economics, 25(6), 739-742.

Britto, G. and McCombie, J. S. L. (2009). Thirlwall's Law and the Long-term Equilibrium Growth Rate: An Application to Brazil. Journal of Post Keynesian Economics, 32(1), 115-136.

Dilber, İ. and Erataş Sönmez, F. (2016). Thirlwall Kanunu'nun Gelişmiş Ülkeler Açısından Geçerliliği: Panel Veri Analizi. Uluslararası Alanya Iş̧letme Fakültesi Dergisi, 8(2), 139-150.

Elitok, P. S. and Campbell, A. (2008). The Balance of Payments as a Constraint on Turkey's Growth: 1960-2004, Working Paper No: 2008-13, Utah University, Department of Economics.

Garcimartin, C. and Rivas A. L. and Sarralde D. D. S. (2008). Accounting for Irish Growth: A balanceof-payments-constraint Approach. Journal of Post Keynesian Economics, 30(3), 409-433.

Gouvea, R. R. and Gilberto T. L. (2010). Structural Change, Balance of Payments Constraint and Economic Growth: Evidence from the Multi-Sectoral Thirlwall's Law. Journal of Post Keynesian Economics, 33(1), 169-204.

Halıcıoğlu, F. 82012). Balance-of-Payments Constrained Growth: The Case of Turkey. Journal of Post Keynesian Economics, 35(1), 65-78.

Hussain, M. N. (1999). The Balance-of-Payments Constraint and Growth Rate Differences among African and East Asian Economies. African Development Review, 11, 103-137.

Kula, F. (2008). Ekonomik Büyüme ve Ödemeler Bilançosu Kısıtı: 1980-2006 Dönemi Türkiye Örneği. Erciyes University Journal of Social Sciences Institute, 1(25), 59-70. 
Kvedaras, V. (2005). Explanation of Economic Growth Differences in the CEE Countries: Importance of BOP Constraint. Baltic Journal of Economics, 2, 48-65.

Lanzafame, M. (2013). The Balance of Payments-Constrained Growth Rate and The Natural Rate of Growth: New Empirical Evidence. Cambridge Journal of Economics, 38(4), 817-838.

Leon-Ledesma, A. M. (1999). An Application of Thirlwall's Law to the Spanish Economy. Journal of Post Keynesian Economics, 21(3), 431-439.

Lopez, G. J. and Alberto, B. C. (2000). Thirlwall's Law and Beyond: The Latin American Experience. Journal of Post Keynesian Economics, 22(3), 477-495.

Loria, E. (2003). The Mexican Economy: Balance-of-payments-constrained Growth model-The Importance of The Exchange Rate, 1970-1999. Journal of Post Keynesian Economics, 25(4), 661-691.

Bertola, L., Higachi, H. and Porcile, G. (2002). Balance-of-Payments-Constrained Growth in Brazil: A Test of Thirlwall's Law, 1890-1973. Journal of Post Keynesian Economics, 25(1), 123-140.

McCombie, S. L. J. (1989). Thirlwall's Law and Balance of Payments Constrained Growth-A Comment on The Debate. Applied Economics, 24(5), 611-629.

McCombie, S. L. J. (1997). On the Empirics of Balance of Payments Constrained Growth. Journal of Post Keynesian Economics, 19(3), 345-375.

McCombie, S. L. J. and Thirlwall, P. A. (1994). Economic Growth and The Balance-of-Payments Constraint, London: The Macmillan Press Ltd.

Moreno-Brid, J. C. and Esteban, P. (1999). Balance of Payments Constrained Growth in Central America: 1950-96. Journal of Post Keynesian Economics, 22(1), 131-147.

Pacheco-Lopez, P. and Thirlwall P. A. (2006). Trade Liberalisation, the Income Elasticity of Demand for Imports and Economic Growth in Latin America. Journal of Post Keynesian Economics, 29(1), 41-61.

Perraton, J. (2003). Balance of Payments Constrained Growth and Developing Countries: An Examination of Thirlwall's Hypothesis. International Review of Applied Economics, 17(1), 1-22.

Pesaran, M. H. (2004). General Diagnostic Tests for Cross Section Dependence in Panels, Working Paper No:0435, University of Cambridge.

Pesaran, M. H. (2007). A Simple Panel Unit Root Test in The Presence of Cross-Section Dependence. Journal of Applied Economics, 22, 265-312.

Pesaran, M. H. and Yamagata, T. (2008). Testing Slope Homogeneity in Large Panels. Journal of Econometrics, 142(1), 50-93.

Podkaminer, L. (2017). Further Evidence on the Validity of Thirlwall's Law. Scientific Journal WSFiP, 5, 75-86.

Razmi, A. (2005). Balance-of-payments-constrained Growth Model: The Case of India. Journal of Post Keynesian Economics, 27(4), 655-687.

Romeo, J. P. and McCombie J. S. L. (2017). Thirlwall's Law and the Specification of Export and Import Functions. Metroeconomica, 69(2), 366-395.

Soukiazis, E. and Antunes, M. (2011). Application of the Balance-of-Payments-Constrained Growth Model to Portugal 1965-2008. Journal of Post Keynesian Economics, 34(2), 353-380.

Thirlwall, P. A. (1979). The Balance of Payments Constraint as an Explanation of International Growth Rate Differences. Banca Nazionale del Lavoro Quarterly Review, 32(128), 45-53. 
Thirlwall, P. A. and Hussain, M. N. (1982). The Balance of Payments Constraint, Capital Flows and Growth Rate Differences between Developing Countries. Oxford Economic Papers, 34(3), 498510.

Tharnpanich, N. and McCombie J. S. L. (2013). Balance of Payment Constrained Growth, Structural Change and the Tai Economy. Journal of Post Keynesian Economics, 35(4), 569-598.

Turner, P. (1999). The Balance of Payments Constraint and the Post-1973 Slowdown of Economic Growth in the G7 Economies. International Review of Applied Economics, 13(1),41-53.

Tuncer, İ., Songur, M. and Demet, Y. (2011). Thirlwall Yasası: Türkiye Ekonomisi Üzerine Bir Uygulama (1982-2010). EconAnadolu 2011: Anadolu International Conference in Economics II, 1-20.

Vera, V. L. (2006). The balance of Payments Constrained Growth Model: A North-south Approach. Journal of Post Keynesian Economics, 26(1), 67-92.

Westerlund, J. (2008). Panel Cointegration Tests of The Fisher Effect. Journal of Applied Economics, 23, 193-233.

Yamak, R. and Abdioğlu, Z. (2010). Thirlwall Yasası: Türkiye Örneği, 1982-2008. Ege Akademik Bakış, $10(2), 443-463$. 